\title{
Movement Patterns of Hooded Seals (Cystophora cristata) in the Northwest Atlantic Ocean during the Post-Moult and Pre-Breed Seasons
}

\author{
Julie M. Andersen and Yolanda F. Wiersma \\ Department of Biology, Memorial University of Newfoundland, \\ St. John's, NL Canada E-mail: j.m.andersen@mun.ca \\ Garry Stenson \\ Science Branch, Department of Fisheries and Oceans, \\ Northwest Atlantic Fisheries Centre, St. John's, NL Canada \\ Mike O. Hammill \\ Dept. of Fisheries and Oceans \\ Mont Joli, Quebec. Canada \\ Aqqalu Rosing-Asvid \\ Greenland Institute of Natural Resources \\ Box 570, 3900 Nuuk, Greenland
}

Andersen, J. M., Y. F. Wiersma, G. Stenson, M. O. Hammill, and A. Rosing-Asvid. 2009. Movement Patterns of Hooded Seals (Cystophora cristata) in the Northwest Atlantic Ocean During the Post-Moult and Pre-Breed Seasons. J. Northw. Atl. Fish Sci., 42: 1-11. doi:10.2960/J.v42.m649

\begin{abstract}
Movement patterns of hooded seals (Cystophora cristata) in the Northwest Atlantic in the period following moulting and prior to breeding are not well known. Here, we describe in detail the movement patterns of 21 seals for this period based on information gathered from satellite linked time depth recorders (SLTDRs). This study provides important baseline information necessary to understand the ecological requirements and patterns in habitat selection for the species. Adult and sub-adult hooded seals were tagged with SLTDRs directly after moulting in SE Greenland during July 2004, 2005 and 2007. Due to variation in tag date and arrival date to the breeding grounds, data between 1 Aug-28 Feb were used which gave all seals a track duration of 211 days (212 in 2005) except for one juvenile where the tag lasted for only 154 days. The tags yielded 36107 location fixes $(\mathrm{SD}=410.64$, mean $=1719.38)$. Although there was individual variation between seal trajectories during migration, the population shared a similar overall pattern. After moulting in July individuals travelled along the continental shelf area up to Davis Strait and Baffin Bay, thereafter moving southwards along the Labrador shelf until they arrived at the breeding grounds by March. Females tended to cut across the Labrador Sea and arrived at the Labrador shelf before heading up to the Baffin Bay area, while males tended to move straight there. The majority of the seals ended up at the Front (off Newfoundland and Southern Labrador) by March although a few of the tagged seals may have belonged to the Davis Strait breeding population and one male belonged to the Gulf of St. Lawrence breeding population. Seven seals displayed an eastward migratory pull and might have overlapped with the Northeast Atlantic population. This would support the theory of a panmitic population structure.
\end{abstract}

Keywords: Cystophora cristata, distribution, hooded seals, movement patterns, Northwest Atlantic Ocean 


\section{Introduction}

The hooded seal (Cystophora cristata) is an abundant, pelagic, deep-diving pinniped distributed throughout the North Atlantic and adjacent Arctic Oceans (Sergeant, 1974; Folkow and Blix, 1995, 1999; Hammill and Stenson, 2006). They breed synchronously during mid- to late March on the pack ice around Jan Mayen ("West Ice"), in Davis Strait between Baffin Is- land and western Greenland, in the Gulf of St. Lawrence (the "Gulf") and off southern Labrador and/or northern Newfoundland (the "Front") (Fig. 1) (Sergeant, 1974, 1976; Hammill, 1993; Folkow et al. 1996). These four breeding herds are considered to belong to two putative populations (Hammill and Stenson, 2006). Hooded seals whelping near Jan Mayen are thought to constitute the Northeast (NE) Atlantic population while hooded seals whelping and breeding in Davis Strait, the Gulf and

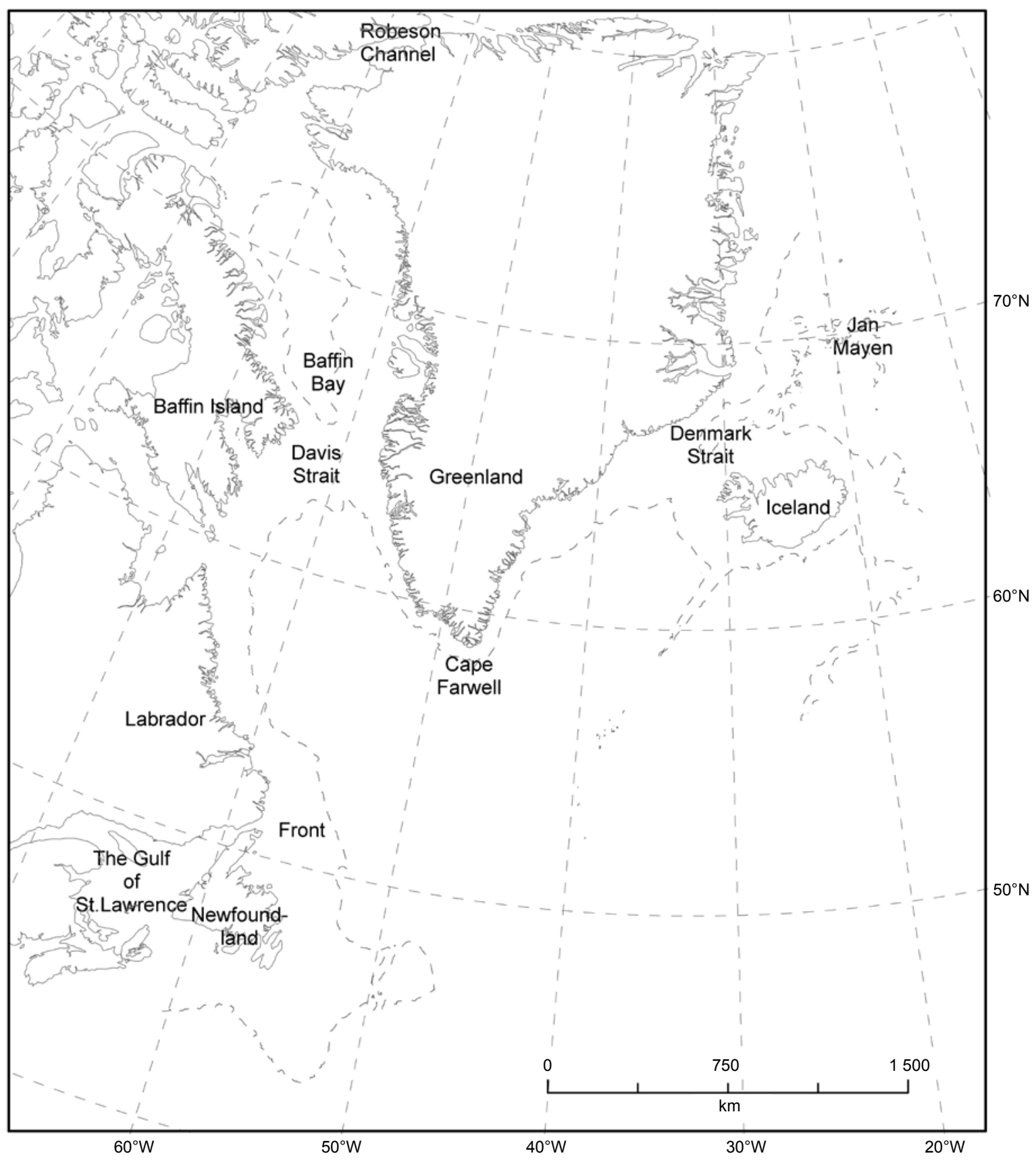

Fig 1. Reference map of the Northwest Atlantic showing locations mentioned in the text. 
at the Front are all thought to belong to the Northwest (NW) Atlantic population (Hammill and Stenson, 2006). The total NW Atlantic population has been estimated to consist of approximately 600000 animals (593 500, $\mathrm{SE}=67$ 200, Hammill and Stenson, 2006), of which $90 \%$ are estimated to whelp at the Front (Stenson et al., 2006). The NE Atlantic population is likely to number between 70000 and 90000 animals, although there is considerable uncertainty around these estimates due to paucity of data and limited understanding of the relationships between whelping areas (WGHARP, 2006).

Coltman et al. (2007) carried out a genetics study across the two populations and found that the Greenland Sea breeding herd was genetically most distant from the NW Atlantic breeding areas; however, the difference was statistically non-significant. The results indicated that the world's hooded seals belong to a single panmitic genetic population, thereby suggesting that there is some overlap in distribution between the NE Atlantic and the NW Atlantic populations. The herd belonging to the NE Atlantic population and whelping around Jan Mayen disperses to sea after breeding in March and some individuals return to the pack ice in the same area in July to moult (Øritsland, 1959; Rasmussen, 1960) while the majority moult further north (Folkow et al., 1996). Following breeding, NW Atlantic hooded seals leave the whelping areas to feed and eventually migrate to the ice off southeast Greenland where they moult in July (Stenson, unpublished data; Sergeant, 1974). After moulting, the general hypothesis has been that most of these animals disperse across the NW Atlantic and up to Davis Strait (Rasmussen, 1960) before migrating southward to the whelping areas.

Preliminary studies have indicated that hooded seals spend much of their time along the edges of the Canadian and Greenland continental shelves or sea mounts (e.g., Flemish Cap, Reykjanes Ridge) where they dive to depths of over $1500 \mathrm{~m}$ (Stenson and others, unpublished data). Due to their pelagic distribution and the lack of knowledge regarding their prey selection at various times of the year, the extent of their fish consumption is difficult to assess (Folkow et al., 1996). However, diet studies indicate that adult hooded seals mainly forage on benthopelagic species (Ross, MS 1992; Hammill and Stenson, 2000; Haug et al., 2007). To a great extent, the role of hooded seals in the marine ecosystem is virtually unknown. However, satellite telemetry allows us to monitor movements of free ranging pinnipeds throughout the year, providing data that have previously been difficult to obtain.

Data from the tags provide us with valuable knowledge of the general movement pattern for hooded seals during the post-moult and pre-breed period which has not been possible to obtain previously. Historical information on marine mammal distributions was provided by shore-based observations, incidental observations from commercial hunting and capture of branded or tagged individuals (Rasmussen, 1960; Sergeant, 1974, MS 1979; Hammill and Stenson, 2006). Although useful, these observations provide more information about the observer effort then the actual distribution of the animals. Satellite telemetry is therefore very valuable in terms of offering continuous distribution information throughout the year which can be projected onto a population level. Here the movement patterns of 21 seals equipped with satellite transmitters were examined for the post-moult and prebreed period (July-March) of their annual migration.

\section{Methods}

Adult and sub-adult hooded seals were tagged with Satellite Linked Time Depth Recorders (SLTDRs) directly after moulting in July in SE Greenland (2004, 2005 and 2007) ( approx. $65^{\circ} \mathrm{N} 37^{\circ} \mathrm{W}$ ). The animals were captured using a net, weighed, and tranquilized using tiletamine hydrochloride and zolazepam hydrochloride (Telazol, AH. Robins Company, Richmond, VZ, USA) administered intramuscularly (1 mg per $100 \mathrm{~kg}$ ). The SLTDRs were designed by the Sea Mammal Research Unit (SMRU) in St. Andrews, Scotland. The transmitters were attached to the head or neck of the seal, using quick drying epoxy glue (Cure 5, Industrial Formulators of Canada Ltd. Burnaby, BC Canada) and the seals were released immediately upon recovery from the tranquilizer. The tag may last up to a year, and is lost when the seal moults the following year.

\section{Seal Locations}

Locations at the surface were determined by the Argos system, and subsequently filtered using an algorithm based on the travelling speed of the tracked animal, distance between successive locations and turning angle (Freitas et al. 2008). We used the algorithms default swim speed of of $2 \mathrm{~m} / \mathrm{s}$.

Distribution maps (Figs. 2 and 3) were created using ArcGIS 9.3 (Environmental Systems Research Institute, Redlands, CA) where the points are represented by filtered locations of seal uplinks throughout their migration. Kernel density maps (Figs. 4 and 5) were created using the package "spatstat" in R (version 2.8.0, The $\mathrm{R}$ Foundation for Statistical Computing) and are based on the total number of filtered uplink locations. These density plots are created using a Gaussian kernel to create smoothed histograms where "sigma" determines the bandwidth of the kernel. Narrower bandwidths yield 


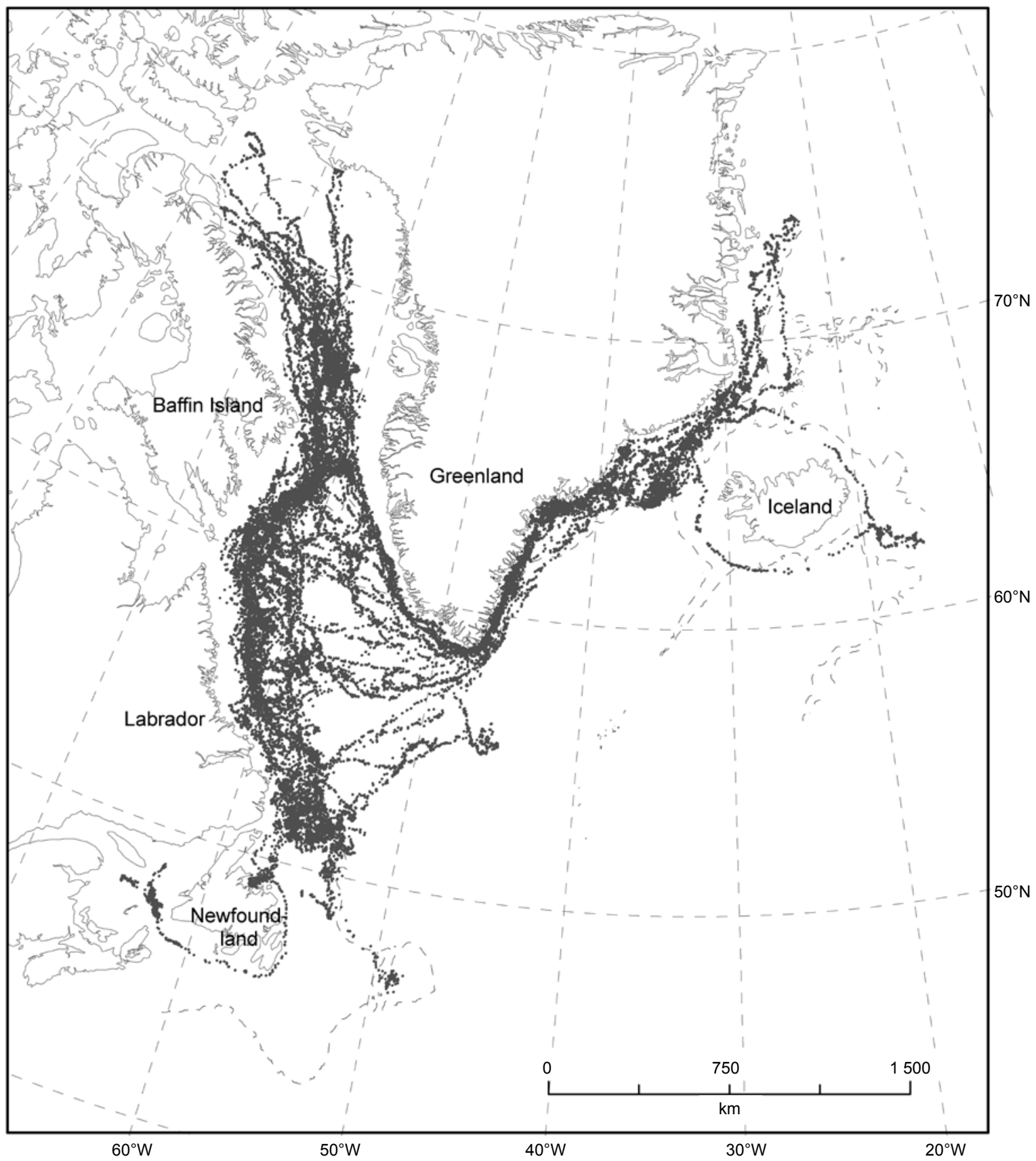

Fig 2. All 21 hooded seal tracks (filtered data) during the study period running from 1 Aug to 28 Feb which is the postmoult pre-breeding migration period for this species. Dashed line is the $1000 \mathrm{~m}$ contour line.

more extreme values and broader bandwidths narrow the interquartile range. The bandwidth used for this study was a sigma value of 0.75 . The darker areas represent locations where the presence of seals caused a higher number of uplinks indicating more time spent in those areas. The resolution of the grid is 20000 meters.

\section{Results}

A total of 26 seals with a post-moulting body mass (BM) range of 73.5-194 kg were caught at approximately at $65^{\circ} \mathrm{N} 37^{\circ} \mathrm{W}$ in SE Greenland in July 2004, 2005 and 2007. Of the 26 seals tagged, 5 were excluded due to mal- 

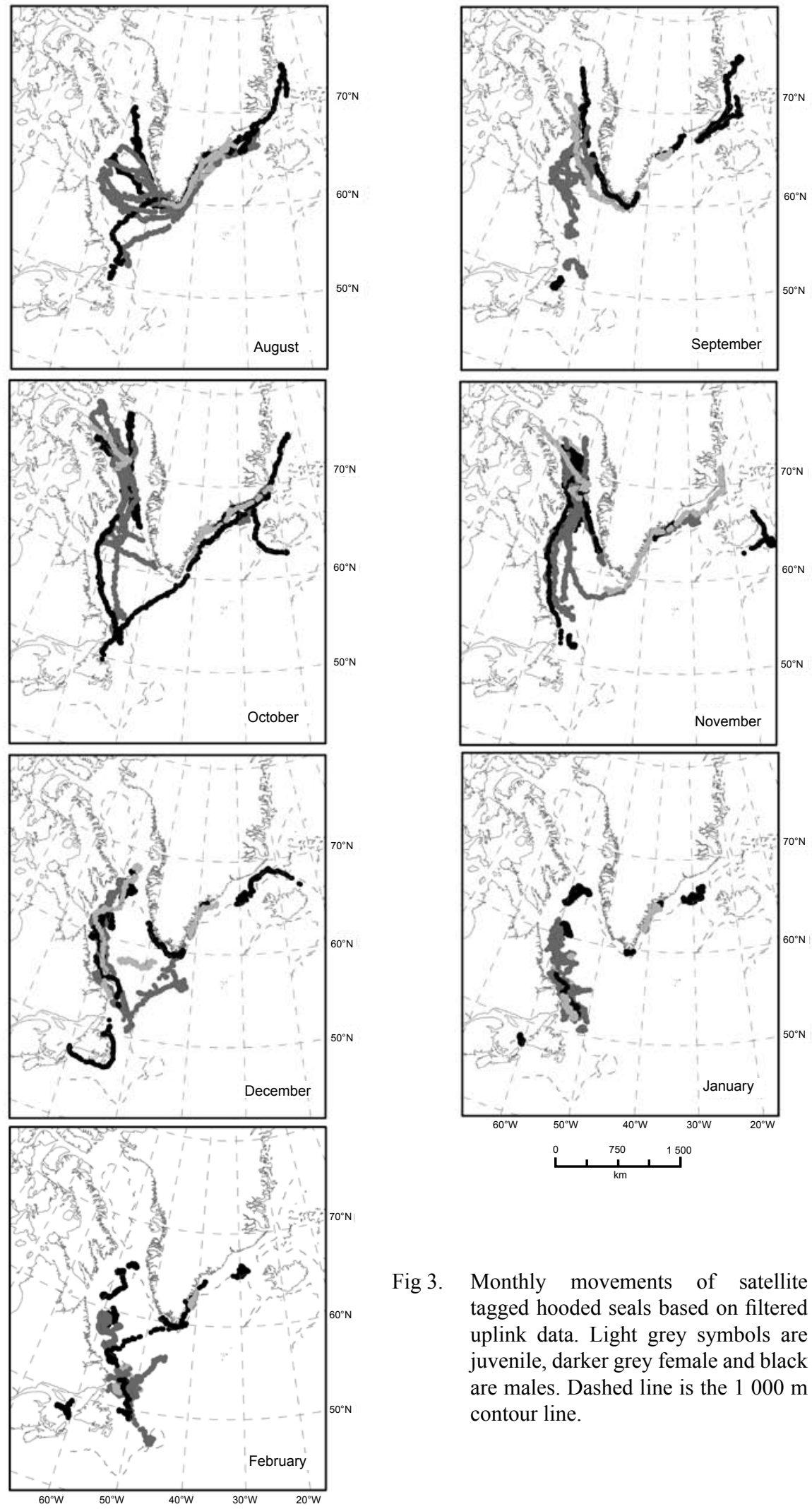

Fig 3. Monthly movements of satellite tagged hooded seals based on filtered uplink data. Light grey symbols are juvenile, darker grey female and black are males. Dashed line is the $1000 \mathrm{~m}$ contour line. 


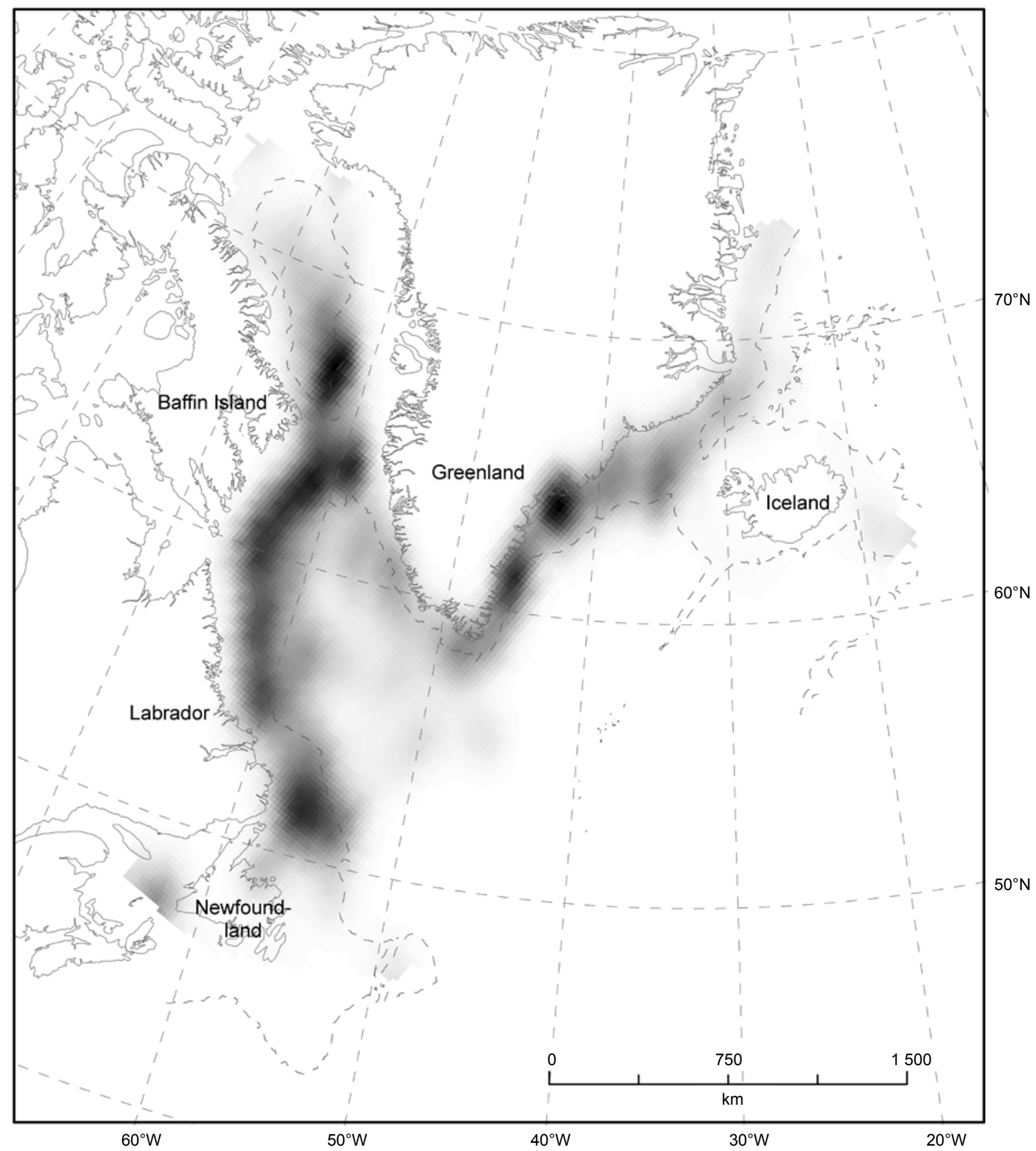

Fig 4. Kernel density surface map displaying the areas of high-use by hooded seals in the NW Atlantic Ocean during the full post-moult pre-breeding migration period based on filtered uplink data. Dashed line is the $1000 \mathrm{~m}$ contour line. Resolution is $20 \mathrm{~km}$.

function within one month of the actual tag date, yielding a sample size of 21 seals ( 9 adult females, 8 adult males and 4 juveniles ( 3 females and 1 male)). Data on the individual seals are presented in Table 1 together with actual tagging locations. Fig. 2 presents combined tracks for the entire study period and Fig. 4 shows the high use areas averaged over the same period. One tag transmitted for 154 days, whereas the rest lasted the entire study pe$\operatorname{riod}(18$ tags $=211$ days, 2 tags $=212$ days (2005)). The tags had a combined transmission period of 4376 days and provided (after filtering) 36107 uplink fixes (SD = 410.64), which gives an average number of 173.31 uplinks each day per seal. The mean total travel distance throughout the period was $14142.05 \pm 2038.92 \mathrm{~km}$. 

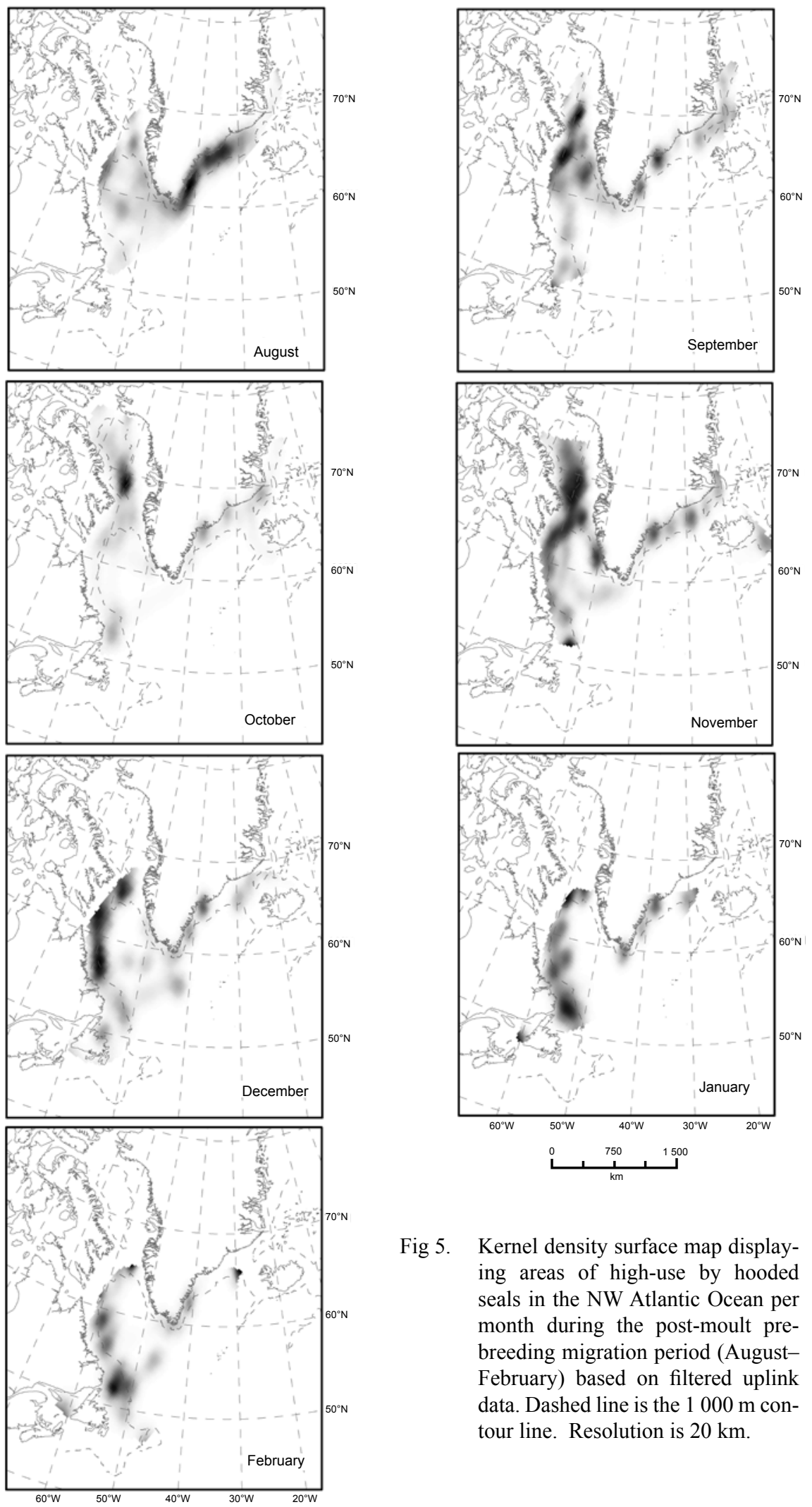

Fig 5. Kernel density surface map displaying areas of high-use by hooded seals in the NW Atlantic Ocean per month during the post-moult prebreeding migration period (AugustFebruary) based on filtered uplink data. Dashed line is the $1000 \mathrm{~m}$ contour line. Resolution is $20 \mathrm{~km}$. 
TABLE 1. Year, Argos PTT identification number, sex, weight at tag date, start and end dates for study period, days transmitted and tagging location of NW Atlantic hooded seals.

\begin{tabular}{|c|c|c|c|c|c|c|c|c|}
\hline Year & PTT \# & Sex & $\mathrm{Wt}(\mathrm{kg})$ & Start & End & $\begin{array}{c}\text { Days } \\
\text { transmitting }\end{array}$ & $\begin{array}{c}\text { Latitude } \\
\text { tagged }\end{array}$ & $\begin{array}{c}\text { Longitude } \\
\text { tagged }\end{array}$ \\
\hline 2004 & 44444 & $\mathrm{~F}$ & 116 & 01 Aug & $28 \mathrm{Feb}$ & 211 & $66^{\circ} 15^{\prime} \mathrm{N}$ & $34^{\circ} 17^{\prime} \mathrm{W}$ \\
\hline 2004 & 44487 & $\mathrm{M}$ & 155 & $01 \mathrm{Aug}$ & $03 \mathrm{Jan}$ & 154 & $66^{\circ} 08^{\prime} \mathrm{N}$ & $34^{\circ} 35^{\prime} \mathrm{W}$ \\
\hline 2004 & 44443 & $\mathrm{~F}$ & 85 & $01 \mathrm{Aug}$ & $28 \mathrm{Feb}$ & 211 & $66^{\circ} 10^{\prime} \mathrm{N}$ & $34^{\circ} 27^{\prime} \mathrm{W}$ \\
\hline 2004 & 44489 & M & 172 & $01 \mathrm{Aug}$ & $28 \mathrm{Feb}$ & 211 & $66^{\circ} 09^{\prime} \mathrm{N}$ & $34^{\circ} 30^{\prime} \mathrm{W}$ \\
\hline 2004 & 49539 & $\mathrm{~F}$ & 81 & $01 \mathrm{Aug}$ & $28 \mathrm{Feb}$ & 211 & $66^{\circ} 15^{\prime} \mathrm{N}$ & $34^{\circ} 17^{\prime} \mathrm{W}$ \\
\hline 2005 & 44486 & $\mathrm{~F}$ & 112 & $01 \mathrm{Aug}$ & $28 \mathrm{Feb}$ & 211 & $65^{\circ} 28^{\prime} \mathrm{N}$ & $36^{\circ} 13^{\prime} \mathrm{W}$ \\
\hline 2005 & 44450 & $\mathrm{M}$ & 127 & $01 \mathrm{Aug}$ & $28 \mathrm{Feb}$ & 211 & $65^{\circ} 31^{\prime} \mathrm{N}$ & $36^{\circ} 21^{\prime} \mathrm{W}$ \\
\hline 2005 & 44448 & $\mathrm{~F}$ & 90 & 01 Aug & $28 \mathrm{Feb}$ & 211 & $65^{\circ} 29^{\prime} \mathrm{N}$ & $37^{\circ} 00^{\prime} \mathrm{W}$ \\
\hline 2005 & 44488 & $\mathrm{~F}$ & 138 & 01 Aug & $28 \mathrm{Feb}$ & 211 & $65^{\circ} 30^{\prime} \mathrm{N}$ & $36^{\circ} 19^{\prime} \mathrm{W}$ \\
\hline 2005 & 49540 & $\mathrm{M}$ & 194 & 01 Aug & $28 \mathrm{Feb}$ & 211 & $65^{\circ} 31^{\prime} \mathrm{N}$ & $36^{\circ} 14^{\prime} \mathrm{W}$ \\
\hline 2005 & 49530 & M & 146 & 01 Aug & $28 \mathrm{Feb}$ & 211 & $65^{\circ} 25^{\prime} \mathrm{N}$ & $36^{\circ} 37^{\prime} \mathrm{W}$ \\
\hline 2005 & 49533 & $\mathrm{~F}$ & 138 & 01 Aug & $28 \mathrm{Feb}$ & 211 & $65^{\circ} 20^{\prime} \mathrm{N}$ & $37^{\circ} 03^{\prime} \mathrm{W}$ \\
\hline 2005 & 49531 & $\mathrm{~F}$ & 95 & 01 Aug & $28 \mathrm{Feb}$ & 211 & $65^{\circ} 20^{\prime} \mathrm{N}$ & $37^{\circ} 06^{\prime} \mathrm{W}$ \\
\hline 2005 & 49537 & $\mathrm{M}$ & 174 & $01 \mathrm{Aug}$ & $28 \mathrm{Feb}$ & 211 & $65^{\circ} 25^{\prime} \mathrm{N}$ & $37^{\circ} 01^{\prime} \mathrm{W}$ \\
\hline 2005 & 49534 & $\mathrm{~F}$ & 117 & 01 Aug & $28 \mathrm{Feb}$ & 211 & $65^{\circ} 19^{\prime} \mathrm{N}$ & $37^{\circ} 11^{\prime} \mathrm{W}$ \\
\hline 2005 & 49535 & $\mathrm{~F}$ & 98 & 01 Aug & $28 \mathrm{Feb}$ & 211 & $65^{\circ} 19^{\prime} \mathrm{N}$ & $37^{\circ} 11^{\prime} \mathrm{W}$ \\
\hline 2005 & 49529 & $\mathrm{~F}$ & 114 & 01 Aug & $28 \mathrm{Feb}$ & 211 & $65^{\circ} 22^{\prime} \mathrm{N}$ & $37^{\circ} 20^{\prime} \mathrm{W}$ \\
\hline 2005 & 44503 & M & 109 & 01 Aug & $28 \mathrm{Feb}$ & 211 & $65^{\circ} 23^{\prime} \mathrm{N}$ & $37^{\circ} 22^{\prime} \mathrm{W}$ \\
\hline 2007 & 44417 & $\mathrm{~F}$ & 73.5 & $01 \mathrm{Aug}$ & $29 \mathrm{Feb}$ & 212 & $65^{\circ} 26^{\prime} \mathrm{N}$ & $37^{\circ} 18^{\prime} \mathrm{W}$ \\
\hline 2007 & 44419 & M & 97.5 & 01 Aug & $29 \mathrm{Feb}$ & 212 & $65^{\circ} 23^{\prime} \mathrm{N}$ & $37^{\circ} 48^{\prime} \mathrm{W}$ \\
\hline 2007 & 44425 & $\mathrm{~F}$ & 130 & $01 \mathrm{Aug}$ & $29 \mathrm{Feb}$ & 212 & $65^{\circ} 23^{\prime} \mathrm{N}$ & $37^{\circ} 55^{\prime} \mathrm{W}$ \\
\hline
\end{tabular}

Due to different tag dates and arrival to the breeding ground, the study period was selected to run from 1 August to 28 February.

The majority of the seals fanned out quite widely, but in similar directions (across the Labrador Sea) immediately after moulting (Fig. 3). The majority of females moved across the Labrador Sea to the Labrador Shelf and Front area, while the males chose a more direct route up to the Davis Strait and Baffin Bay area along the continental shelf off western Greenland. Seven animals stayed behind in Greenland for a longer period of time: one female juvenile (\#44443) stayed in the moulting area throughout the migration period apart from a few shorter trips along the SE Greenland coast and into the Denmark Strait. This female never migrated to the breeding areas. A young male (\#44487) stayed behind in the moulting areas until November, at which point he started to move south, crossing the Labrador Sea towards the Front in December. The signal was lost on 3 January 2005 when the male was mid basin. Female \#44488 moved northeast into the Denmark Strait and did not migrate across the Labrador Sea towards the Front until December. This female then stayed in the Front area until breeding. Male \#44489 was the only seal to head straight northeast through the Denmark Strait following the Greenland shelf all the way up to the area off Danmark Havn $\left(\sim 75^{\circ} 07^{\prime} \mathrm{N} 13^{\circ} 03^{\prime} \mathrm{W}\right)$. This male picked up speed in October and headed south straight across the Labrador Sea to the Front. Male \#44503 migrated north following the same pattern as \#44489, but turned around and migrated south of Iceland, along the Faeroe-Iceland ridge and back on the north side of Iceland, ending up in the Denmark Strait by the end of February. Male \#49537 stayed in the moulting area the entire time until February when it abruptly migrated to the Front. Only one of the tagged seals was a Gulf breeder (\#49540) and was the only male to cut straight across the Labrador Sea after moulting to the Front before heading up along the continental shelf area. This seal made a quick loop into Baffin Bay before heading back down to the Front by end of November and from there travelled south of Newfoundland arriving in the Gulf of St. Lawrence by the end of December. Males \#44450 and \#44419 ended 
up in Davis Strait by end February indicating that they were not breeding or they may have belonged to the Davis Strait breeding herd.

Although the seals fanned out in various directions in August, many of them gathered in Baffin Bay and Davis Strait by October and November which may indicate that these are important feeding areas for the population (Figs. 3 and 5). The Labrador shelf, the Front and SE Greenland may also be important habitat locations for this species based on travel and kernel density patterns (Fig. 5). The rest of the study area seemed to be used for travelling or shorter foraging trips.

\section{Discussion}

This study is the first to illustrate the movement patterns of the NW Atlantic hooded seals during their post-moult, pre-breed migration. To date, there has been limited information about the annual migration of this species, but this study reveals that they travel large distances during this time. Although there is individual variation in trajectories chosen, the overall picture of how these animals move throughout the NW Atlantic seem to be similar throughout the population. This differs somewhat to Folkow et al.'s (1996) findings for the NE Atlantic population's migration pattern. They found that the migrations of these seals to distant waters were not synchronised in time and that they did not display a general seasonal migration pattern (Folkow et al., 1996). However, the NW Atlantic population did demonstrate a similar pattern in choice of feeding areas and there was general synchrony, with some individual variation. The seals all started their migration after their annual moult and seemed to head in various directions. However, most start to come together in September along the continental shelf, Davis Strait and in Baffin Bay (Fig. 3), presumably for feeding as this is an important period for them to put on weight after the moult and preparing themselves for the whelping and breeding season. The choice of feeding areas appear to be closely related to areas of high topographic relief as the seals tend to stay close to the $1000 \mathrm{~m}$ contour line along the Labrador shelf area as well as in the Baffin Bay basin. Baffin Bay and the eastern Canadian High Arctic have a complex coastline, an influx of warm Atlantic water along the West Greenland coast, and a restricted opening to the polar basin through Robeson Channel (Heide-Jørgensen and Laidre, 2004) in the north. This results in numerous microhabitats in the region which may result in the high abundance of animals overwintering there (Heide-Jørgensen and Laidre, 2004). Some species which overlap with the range of hooded seals in this area include marine mammals such as beluga (Delphionpterus leucas), narwhal (Monodon monoceros) and bowhead whales (Balaena mysticetus), as well as various species of seabirds (Heide-Jørgensen and Laidre 2004; Laidre et al., 2003, 2004, 2007). There may be some overlap in prey preference between beluga, narwhal and hooded seals (e.g., Greenland halibut (Reinharditus hippoglossoides)) (Richard et al., 1998; Laidre et al., 2004) in these areas. The aspects of how oceanographic processes and prey distribution may drive hooded seal habitat use (including their diving behaviour throughout their migration) will be the subject of future research.

Areas along the Labrador shelf and the Baffin Bay basin appear to be important feeding areas while the Labrador Sea and the west coast of Greenland appear to be areas where the seals move through at a higher speed (Fig. 4). Even though the seals may have a wide movement range during certain months (Fig. 3), the high-use areas are actually rather small (Fig. 5). Some of the highuse areas could be biased due to a higher number of seals moving through a specific location during the month resulting in a higher number of uplinks at a particular point (e.g. Fig. 5: August is when the seals start moving out of the moulting patches which were located in the same general area). It is not expected that hauling out on ice will bias the results too much due to the fact that the tags will stop transmitting if dry for more than six hours. By September the seals arrived on the shelf area in southern Davis Strait and in the southern Baffin Bay basin. In October the seals appeared to spend more time in the latter, while the movement range of the seals during that month was very wide (Fig. 3). During the month of November the seals display a more general use of Baffin Bay and Davis Strait, and they started to move south along the Labrador Shelf; by December they were all south of Baffin Bay spending time in Davis Strait and on the Labrador Shelf. That seals feeding in Baffin Bay move south after November may be influenced by the build-up of ice in the area forcing the seals southwards. Another possibility could be due to colder water temperatures forcing prey to deeper depths thereby increasing the cost of feeding. January appears to be a month when the seals stay in more restricted areas (Front and in the Davis Strait) which could also be due to ice conditions, while in February seals started to move across somewhat longer distances again, perhaps to obtain a good position for breeding. There was a high-use area in the southern Denmark Strait which is caused by one seal's intense use of a small area that month. The rest of the seals were spread out along the Front area and Labrador shelf up to Davis Strait.

There appears to be a difference between sexes in the initial choice of feeding areas. Females crossed the Lab- 
rador Sea and arrived earlier onto the continental shelf area off Labrador (Fig. 3, August), while males took a more direct route up to Davis Strait and Baffin Bay. Because the hooded seal is a sexually dimorphic phocid, the different choice in initial feeding area may be due to different dietary requirements (Hammill and Stenson, 2000) after the moult. Recent studies have shown that although there is an overlap between males and females on a horizontal plane during feeding migrations after the breeding season, they display differences in foraging depths. Females tend to make more shallow dives than males preceding the migration and deeper dives after the migration (Bajzak et al., 2009). The feeding behaviour and diving during post-moult and pre-breed seasons has not yet been investigated; however this study indicates that there is less horizontal overlap initially between sexes during this period.

Two female juveniles (\#49539 and \#44417) migrated to Baffin Bay by the end of September, moving south with the rest of the animals and ending up at the Front by end of February. They may not have ended up at the breeding patch by March, or they could possibly be first time breeders. Female \#44486 arrived at the Front by the beginning of February, but migrated back across the Labrador Sea to Cape Farewell by the end. This may have been a detour, or perhaps this female did not breed that year. There is also a possibility that this female continued up to the West Ice where the NE Atlantic population breeds in late March (e.g., Øritsland, 1959; Rasmussen, 1960). The seven seals which stayed behind in Greenland for a longer period of time executing migrations up to Denmark Strait and \#44503 who travelled to Faroese waters before ending up back in Denmark Strait by the end of February offers a strong indication that there is an overlap between the two populations, as has been suggested in earlier studies (Rasmussen, 1960; Coltman et al., 2007). The NE Atlantic population spends longer periods of time in the Denmark Strait, around Iceland and Jan Mayen ("West Ice") and are found to be present in waters off the Faeroe Islands during all months of the year (Folkow et al., 1996). The findings in this study therefore support the genetic study carried out by Coltman et al., (2007) who suggested that North Atlantic hooded seals consists of one panmitic population.

This study provides new and valuable information on the possible locations of critical habitat for hooded seals. Further investigation of the telemetry data used will include exploring how the physical environment affects hooded seal migrations and their diving behaviour throughout the full year. Such studies will improve our understanding of the role this species play in the Northwest Atlantic ecosystem.

\section{Acknowledgements}

We would like to thank D. McKinnon and D. Wakeham for help in capturing the seals and deploying the transmitters. Lise Langgård, Tore Haug, and two anonymous reviewers provided valuable feedback on an earlier draft of the manuscript. We would also like to thank Roger Bivand at the Norwegian School of Economics and Business Administration and the LESA lab crew at Memorial University of Newfoundland for valuable input. This work was funded through the Atlantic Seal Research program, the International Governance Program (DFO) and by Greenland Institute of Natural Resources as well as a CFI grant to $\mathrm{YW}$.

\section{References}

BAJZAK, C. E., S. D. CÔTE, M. O. HAMMILL, and G. STENSON. 2009. Intersexual differences in the postbreeding foraging behavior of the Northwest Atlantic hooded seal. Mar. Ecol. Progr. Ser., 385: 285-294. doi:10.3354/ meps08015

COLTMAN, D. W., G. STENSON, M. O. HAMMILL, T. HAUG, C. S. DAVIS, and T. L. FULTON. 2007. Panmitic population structure in the hooded seal (Cystophora cristata). Mol. Ecol., 16: 1639-1648. doi:10.1111/j.1365294X.2007.03229.x

FOLKOW, L. P., and A. S. BLIX. 1995. Distribution and diving behavior of hooded seals. In: A. S. Blix, L. Walløe and Ø. Ulltang (eds.). Whales, Seals, Fish and Man. Elsevier, Amsterdam, p. 193-202.

1999. Diving behaviour of hooded seals (Cystophora cristata) in the Greenland and Norwegian Seas. Polar Biol., 22: 61-74. doi:10.1007/s003000050391

FOLKOW, L. P., P. E. MÅRTENSSON, and A. S. BLIX. 1996. Annual distribution of hooded seals (Cystophora cristata) in the Greenland and Norwegian Seas. Polar Biol., 16: 179-189. doi:10.1007/BF02329206

FREITAS, C., C. LYDERSEN, M. A. FEDAK, and K. M. KOVACS. 2008. A simple new algorithm to filter marine mammal Argos locations. Marine Mammal Science, 24: 315-325. doi:10.1111/j.1748-7692.2007.00180.x

HAMMILL, M. O. 1993. Seasonal movements of Hooded seals tagged in the Gulf of St. Lawrence, Canada. Polar Biol., 13: 307-310. doi:10.1007/BF00238357

HAMMILL, M. O., and G. STENSON. 2000. Estimated prey consumption by harp seals (Phoca groenlandica), hooded seals (Cystophora cristata), grey seals (Halichoerus grypus) and harbour seals (Phoca vitulina) in Atlantic Canada. J. Northw. Atl. Fish. Sci., 26: 1-23. doi:10.2960/J. v26.a1

2006. Abundance of Northwest Atlantic hooded seals (1960-2005). DFO Canada. Canadian Science Advisory Secretariat Research Document 2006/068. 19 p. http:// www.dfo-mpo.gc.ca/csas/

HAUG, T., K. T. NILSSEN, L. LINDBLOM, and U. LINDSTRØM. 2007. Diets of Hooded seals (Cystophora 
cristata) in coastal waters and drift ice waters along the east coast of Greenland. Mar. Biol. Res., 3: 123-133. doi:10.1080/17451000701358531

HEIDE-JØRGENSEN, M. P., and K. L. LAIDRE. 2004. Declining extent of open-water refugia for top predators in Baffin Bay and adjacent waters. Ambio, 33: 487-494.

LAIDRE, K. L., M. P. HEIDE-JØRGENSEN, R. DIETZ, R. C. HOBBS, and O. A. JØRGENSEN. 2003. Deep-diving by narwhals Monodon monoceros: differences in foraging behavior between wintering areas? Mar. Ecol. Progr. Ser., 261: 269-281. doi:10.3354/meps 261269

LAIDRE, K. L., M. P. HEIDE-JØRGENSEN, M. L. LOGSON, R. C. HOBBS, P. HEAGERTY, R. DIETZ, O. A. JØRGENSEN, and M. A. TREBLE. 2004. Seasonal narwhal habitat association in the high Arctic. Mar. Biol., 145: 821-831.

LAIDRE, K. L., M. P. HEIDE-JØRGENSEN, and T. G. NIELSEN. 2007. Role of bowhead whale as a predator in West Greenland. Mar. Ecol. Prog. Ser, 346: 285-297. doi:10.3354/meps06995

ØRITSLAND, T. 1959. Klappmyss (The hooded seal). Fauna Oslo, 12: 70-90.

RASMUSSEN, B. 1960. Om Klappmyssbestanden i det nordlige atlanterhav (on the stock of hooded seals in the northern Atlantic). Fisken og Havet, 1: 1-23 (Fisheries Research Board of Canadian Translation series No 387, 28 p., typescript).
RICHARD, P. R., M. P. HEIDE-JØRGENSEN, and D. ST. AUBIN. 1998. Fall movements of belugas (Delphinapterus leucas) with satellite-linked transmitters in Lancaster Sound, Jones Sound, and Northern Baffin Bay. Arctic, 51: $5-16$.

ROSS, S. A. MS 1992. Food and Feeding of the hooded seal (Cystophora Cristata) in Newfoundland. M.Sc. Thesis Memorial University of Newfoundland. St. John's, Newfoundland.

SERGEANT, D. E. 1974. A rediscovered whelping population of hooded seals, Cystophora cristata Erxleben, and its possible relationship to other populations. Polarforschung, 44: 1-7.

1976. History and present status of populations of harp and hooded seals. Biol. Conserv., 10: 95-118.

MS 1979. Results of Tagging and Branding of Hooded Seals, 1972-1978. International Commission for the Northwest Atlantic Fisheries. ICNAF Res. Doc. 78/XI/86, Serial No. 5302, 4 p.

STENSON, G. B., M. O. HAMMILL, J. LAWSON, and J. F. GOSSELIN. 2006. 2005 Pup production of hooded seals, Cystophora cristata, in the Northwest Atlantic. DFO Canada. Canadian Science Advisory Secretariat Research Document 2006/067, 44 p. http://www.dfo-mpo.gc.ca/ csas/

WGHARP. 2006. Report of the ICES/NAFO Working Group on Harp and Hooded Seals. ICES, Copenhagen, 28 p. 